\title{
Building SMEs' Competitive Advantage and the Organizational Agility of Apparel Retailers in Indonesia: The role of ICT as an Initial Trigger
}

\author{
Acbsanul Qosasi, ${ }^{1}$ Erwin Permana, ${ }^{2 *}$ Anang Muftiadi, ${ }^{3}$ Margo Purnomo, ${ }^{3}$ and Erna Maulina ${ }^{3}$ \\ ${ }^{1}$ Audit Board of the Republic of Indonesia (Badan Pemeriksa Kenangan RI), Jakarta, Indonesia; \\ ${ }^{2}$ Bina Nusantara (BINUS) University, Jakarta, Indonesia; \\ ${ }^{3}$ Padjajaran University, Bandung, Indoneisa
}

\begin{abstract}
The use of Information and Communication Technology (ICT) could make Small Medium Enterprises (SME) capable of capturing future potential markets. This study investigates how the use of ICT affects firms' agility and finally ends in their competitive advantage. In other words, this study examines how firms' ICT capabilities directly enhance their competitive advantage. Their ICT capability also affects the firms' competitive agitlity indirectly by mediating their business agility. This study infers that if small business firms would like to enhance their supply chains and customer relationship management, they should adopt ICT as a tool to transform their businesses. This transformation improves small firms' competitiveness levels because it allows them to manage all their customers. Meanwhile, the small business firms could enhance their agility due to their suppliers' closeness. This means that the small business firms have posited the concepts and philosophy suggested by the resources dependent theory.
\end{abstract}

Keywords: ICT capability; organisational agility; competitive advantage and small business

JEL classification: $\mathrm{M} 15, \mathrm{O} 32, \mathrm{O} 33$

* Corresponding author's e-mail: win.buyung@gmail.com 


\section{Introduction}

A company or firm always uses its competitiveness and agility to win market share. It should always transform its internal business processes so its agility can be used to capture a greater share of the potential market. Power et al. (2001) suggested that the concept of agility is holistic and strategic, and it is more than just a functional and tactical concept. Goldman et al. (1995), and Tsourveloudis et al. (1999) argued that agility is a holistic tool supporting a firm's strategy. They also stated that agility is a business-wide capability that embraces organizational structures, information systems, logistics processes and, in particular, mindsets. This study posits that agility has a broad implementation, so that a firm could manage its internal factors, utilize its ICT, and measure, as well as control, its staffs' output and behavior.

This study explores the idea that Indonesian small business firms should adopt ICT if they want to maintain their growth and succeed in the global market. This research offers support for this specific idea with the following arguments: First, it is crucial that small businesses have traditional markets, and they support the national economy. However, a small business operating in a traditional market generally faces two obstacles, which are the internal and external constraints. The internal constraints are the business's weak resources, management, bargaining power, and legality, while the external constraints are the competitiveness challenges affected by the globalization of business, such as modern markets, the development of information and communication technology, the fluctuating prices of goods, and the changes in the consumers' demands. These constraints become the regulatory and public concerns for business actors, and for the competitiveness of small businesses in traditional markets; especially since Indonesia still needs the existence and the sustainability of traditional markets in the current business environment.

Second, this study supports evidence that the Indonesian government has responded to the phenomena stated above. The Provincial Government of Jakarta, through the local-government-owned-enterprise PD Pasar Jaya, revitalized all of the traditional markets in four ways. Firstly, the provincial government fully empowered the infrastructure, including all the outlets and buildings. It also cooperated with all the small businesses to open new potential markets. Moreover, the provincial government increased their facilitation with adequate infrastructure. The infrastructure improvements were to ensure that the site functions as a place that traders and buyers can undertake their transactions conveniently. Secondly, the provincial government collaborated with the Indonesian Market Operators Association (Asparindo) to enhance all the small businesses with ICT, to encourage them to be involved with e-commerce trading methods. They conducted e-commerce training, launched the OYES application (shopping application for market traders), introduced a financial technology system called JAKmikro (community economic empowerment program through digitalization of small and medium enterprises), and intensified educational assistance to the small businesses' traders. All these activities were conducted to motivate all the traditional traders to adopt the digital ecosystem and to encourage them to use electronic money in every transaction. 
Thirdly, this study conducted preliminary field observations and found out that small businesses which are apparel retailers had a higher level of competitiveness than those that sold vegetables, fruit, and groceries. This highlights that governmental empowerment of online shopping activities has changed consumers' behavior, in that they no longer need to come to the stores' locations. The government's attention to e-commerce, proposed by Law No. 19 of year 2016, which is about information and electronic transactions security, is not only to protect consumers when they perform transactions but also the traders. Therefore, it will encourage buyers and sellers to transact via online media within the broad community. Finally, the research investigates the relationship between the support provided by the Jakarta provincial government and the sustainability of traditional markets.

The power of traditional markets in the centre of apparel retailers in Jakarta is the achievement of their competitive advantage collectively. This is due to the increasing competition in the market. The fact shows that the business owners at the centre of the garment trade in PD Pasar Jaya do not only compete with their fellow business actors, but also with the modern shopping and e-commerce centres. This current phenomenon shows that small businesses in traditional markets, especially in the apparel trade in Jakarta, join in e-commerce with big brands like Tokopedia, Bukalapak, Lazzada, Shopee, Kaskus and others. It indicates that SMEs in the apparel retail trade in traditional markets have realized the importance and capability of information and communication technology to produce a competitive advantage for them, to ensure their businesses' continuity.
The response of PD Pasar Jaya, as the controller and manager, was to revitalize the use of technology for small business firms in the traditional markets in Jakarta. Moreover, the willingness of small businesses to utilize technology's capabilities led to their ability to have organizational agility. These indications are in accordance with the opinions of experts (Bagheri et al. 2013; Roberts and Grover 2012; Sambamurthy et al. 2003; Singh et al. 2007; Yaghoobi et al. 2014). It means that their organizational agility is the speed at which they can change and adapt to the business environment where the companies are located.

Business agility, facilitated by communication and information technology in the operation of small apparel retail outlets in traditional markets in Jakarta, also indicates that transactions are not only dependent on the local market in Jakarta. For example, the apparel traders at Tanah Abang Market, Jatinegara Market, Mayestik Market, Cipulir Market, and Blok M Square Market have product providers or suppliers who import their goods from China, Thailand, Singapore, and Korea. There is an indication that small businesses in the garment trade in traditional markets in Jakarta have relationships with customers in Bogor, Tangerang, Bekasi (known as BOTABEK) and customers in other big cities such as Bandung, Surabaya, Medan, Makassar, Semarang, and Yogyakarta. They imported their merchandise from neighbouring countries such as Malaysia, Singapore and Brunei Darussalam.

The main characteristic of agility is that the companies have flexible operations and can adjust their businesses quickly to respond to any environmental changes ( $\mathrm{Lu}$ and Ramamurthy 2011). Lu and 
Qosasiet al.

Ramamurthy (2011) stated that companies whose agility is high would undoubtedly adjust to new market conditions through changes in the flow of their business operations or organizational arrangements. Therefore, organizational agility could be attributed as a skill that is useful to adjust a company's operations. Moreover, if they are agile, small business firms could take on market opportunities, since they could solve any business problems quickly, which is advantageous for them. This study called that ability organizational agility in market utilization (Goldman et al. 1995; Lu and Ramamurthy 2011; Tsourveloudis et al. 1999).

This study conducts previously undertaken mapping (Systematic Literature Review/SLR), with the category of focusing research on competitive advantage for small businesses. The researcher found four articles that had clothing industries or fashion as the locus of their research. This study infers that the research into information technology and communications' capabilities could enhance small businesses' competitive advantage, through their agility, especially in the apparel trade in Jakarta, Indonesia. Thus, the researchers expected to produce recommendations focusing and shaping a conceptual basis for the development of the agility of small garment businesses in Indonesia. Finally, this study would answer how the information and communication technology's capability affected the small businesses' competitive advantage through their organizational agility, especially for garment retailers in Jakarta.

\section{Literature Review}

Organizational Agility, ICT Capability, and Competitive Advantage

$\mathrm{Lu}$ and Ramamurthy (2011) defined organizational agility as the ability to detect opportunities for innovation, and being able to seize those competitive market opportunities by assembling important assets, knowledge, and relationships with speed and surprise. Lu and Ramamurthy (2011) and Volberda (1996, 1997) define organizational agility as the ability of an organization to detect opportunities to create innovation, through which the company will seize competitive market opportunities through the use of the required assets, and the use of its organizational knowledge, in an appropriate manner, in unpredictable market conditions.

The research of Gaddis (2000) and Roberts and Grover (2012) found that organizational agility has emerged as a critical corporate capability in today's highly competitive business environment (Gaddis 2000; Roberts and Grover 2012). The results of the extant study refer to the ability of companies or organizations to feel and quickly respond to changes in the market's environment, which have an impact on the companies' operations management. Indeed, a company's reaction will be such that it can adapt to the changes by involving and reconfiguring the company's resources (Roberts and Grover 2012). 
Grant's research (1996), re-examined by Ayabakan et al. (2017), described the hierarchical structure of capabilities within a company, where those at a low-level lead to higher order abilities. High-level abilities create a differential advantage for a company, because they are precious and rare. From this perspective, the organization develops its agility as a high-level dynamic capability by developing its work routines and utilizing a low-level dynamic capability (such as the use of ICT). Therefore, ICT is enabling the small business firms to align, improve, and reconfigure their capabilities and other resources (Teece 2007 ).

Based on the results of mapping conducted by researchers, organizational agility is a new concept in the 21st century, and one of the early definitions of organizational agility in strategic management, as proposed by Judge and Miller (1991), is the speed of the organization in making decisions. After that, organizational agility is also referred to as flexibility. According to Bahrami (1992), flexibility is the ability to change rapidly to take advantage of emerging opportunities and side-step threats. The meaning of organizational agility is generally characterized as the responsiveness to the environment and adaptive change.

Some of the researchers who initiated the transition from flexibility to organizational agility were Sambamurthy et al. (2003) and Lu and Ramamurthy (2011). The researchers used the concept of agility, according to $\mathrm{Lu}$ and Ramamurthy (2011), who stated that agility is the ability to detect opportunities for innovation and seize those competitive market opportunities by assembling important assets, knowledge, and relationships with speed and surprise. This study posits that there are two dimensions involved in organizational agility: agil- ity in adjusting company operations; and agility in utilizing the market.

Organizational agility is a dynamic action that involves aspects of perception and decision-making factors such as anticipation, visual mapping, knowledge of a condition, and patterns; and the speed of changes in direction (Wiklund and Shepherd 2003). Organizational agility is the ability to capture environmental changes and to respond quickly and efficiently (Yaghoubi and Tajmohammadi 2011). Yusuf et al. (1999) stated that organizational agility is concerned with the ability of an organization to integrate its ICT capability in order to provide products and services in different environments and dynamic markets. Meanwhile, Yaghoobi et al. (2014) found that leadership, culture, and technology affect organizational agility. Unlike in organizations that do not have agility, an organizational culture which is agile is dynamic. It means that this study argues that culture constructed the firms' leadership, based on trust, confidence, and respect for their employees.

Research in the field of ICT such as that conducted by Lu and Ramamurthy (2011), Goldman et al. (1995) and Tsourveloudis et al. (1999), showed that technology had affected companies' agility. The use of ICT determines their flexibility to change SMEs' supply chains and customer relationships (Goldman et al. 1995; $\mathrm{Lu}$ and Ramamurthy 2011; Somsuk et al. 2012; Tsourveloudis et al. 1999; Werr et al. 2009). Therefore, this study argues that their information and communication technology capabilities affect their agility.

The use of ICT for competitive advantage is theoretically based on the resource-based theory of the firm (Penrose 1959; Wernerfelt 1984) or the resource 
based view (Barney 1991). In other words, it is called the perspective of the dynamic capability theory (Teece et al. 1997). Teece et al. (1997) explained that the relationship among them is as follows. ICT and competitive advantage capture the ability to utilize Information Technology (IT) to enable firms to adapt faster to external changes than their competitors, hence, providing them with a sustained competitive advantage (Jared et al. 2015). Therefore, having an ICT capability is aimed at achieving or maintaining a firm's competitive advantage (Nguyen 2010; Teece and Leih 2016). They defined companies' capabilities as their ability to carry out their tasks or activities to achieve their corporate objectives (Chibelushi and Trigg 2012; Escandón-Barbosa et al. 2016; Shafei and Zohdi 2014). Information technology is a set of tools used by an organization to produce, process and disseminate information. Therefore, information technology provides support for companies' operations (Qosasi and Permana 2017). Thus, their ICT capability is the companies' ability to utilize digital media or ICT to support their business operations and marketing (Qosasi and Permana 2017).

Liu and Fang (2016) argued that having a competitive advantage means that companies can create more economic value than their competitors can (Porter 1985). Newbert (2008) extended Porter's concept and asserted that competitive advantage is the implementation of corporate strategies to achieve cost reduction goals, to exploit market opportunities, and to neutralize competitive threats. Small businesses are currently required to have the dynamic ability to respond to market changes, to shorten their product cycles, and to change or to reorientate their consumers' demands (Uden 2007). Under these conditions, small business organizations need to be faster, more flexible, and participatory (Sussan and Johnson, 2003) and to be faster, sharper, and more resilient (Wang and Ahmed 2007).

Baker (1996) suggested that firms could achieve this agility if they could respond to market changes dynamically, and they had high flexibility to adjust to the environmental instability. Firms' dynamic capabilities are seen when they can adapt to their market's changes, and environmental instability (Wang and Ahmed 2007). Finally, organizational agility is the primary key to gaining a competitive advantage, when competitors can not compete and imitate immediately (Yaghoobi et al. 2014). This study posits Baker (1996), Wang and Ahmed (2007) and Yaghoobi et al. (2014), who all argue the relevance between firms' ICT adoption and their dynamic capabilities. This study also argues that firms whose ICT capabilities are high, can respond to market changes and environmental instability. Therefore, these firms could achieve a higher level of competitiveness, in comparison with firms with a low ICT adoption rate. Moreover, this study argues that firms which adopted ICT tend to have a broad marketplace, guaranteeing their high future cash inflows. Therefore, this study formulates the first hypothesis as follows:

\section{$H_{i}$ : Firms' ICT capability affects their busi- ness agility positively.}

Equivalent to the first hypothesis, this study argues that ICT's adoption influences not only their agility but also their competitive advantage. When firms adopt ICT, they transform their businesses by building a closer relationship with their supply chains and customers. It means that they cut their related costs. Meanwhile, 
they can also widen their market. This means that they can probably generate potentially greater future cash inflows than firms without ICT. Therefore, this study proposes that these firms possess a higher competitive advantage and thus constructed the following hypothesis:

$H_{2}$ : Firms' ICT capability affects their competitive advantage positively.

After the firms adopted ICT, they probably obtained their agility. Moreover, when the firms achieved their agility, they could respond to market changes dynamically, and they had high flexibility to adjust to the environmental instability (Baker 1996). This study concludes that these firms had competitiveness because of their dynamic capability. It means that they could change their strategies swiftly due to their ICT's capability. This study also argues that firms' business agility mediates the relationship between their ICT capability and competeitive advantage. Whether the firms' business agility could increase their competeitive advantage is not certain, but their business agilities had been supported by their ICT capabilities. Therefore, this study constructs the third hypothesis as follows:

\section{$H_{3}$ : Firms' business agility affects their com- petitive advantage positively.}

\section{Methods}

The respondents of this research are small apparel retail actors in Jakarta. Determination of the number of respondents refers to the expert's point of view. Suwarno (2002) proposed that the number of Structural Equation Modeling (SEM) analysis samples that provide a reasonably stable result is between 200 to 600 respon- dents. Meanwhile, Hair et al. (2006) suggested that the sample size is approximately between five to 10 times the number of the expected model's coefficients. The number of questionnaire items in this study was 65 items. When referring to Hair et al. (2006), the number of research respondents ranged from 300 to 600 respondents. While the real number of respondents that were successfully obtained was 462 respondents from small-scale businesses. Furthermore, the number of research respondents covered several sampling theories proposed by these experts. The respondents have the following criteria:

1. They meet the criteria for a small business that sells apparel in accordance with Law No. 20 of year 2008 on Micro, Small and Medium Enterprises.

2. They had been recorded as an apparel trader operating in traditional market in Jakarta for at least two years.

3. They have used information and communication technology applications in their business, for maintaining their relationships with consumers, employees, and partners.

This study used organizational unit analysis. This study collected data by face to face meetings and via electronic media because of its purposive sampling method. This study, therefore, collected and tabulated the data in a spreadsheet; this study examined the collected data by following a set order: the tests for validity, reliability, and goodness of fit model. The tests are conducted to help construct the research model. Finally, this study took statistical inferences from all the tests' results. The data's analysis uses Structural Equation Modeling (SEM) with SmartPLS software. Structural Equation Model (SEM) is a set of 
statistical techniques that allow for the testing of a series of relatively "complicated" relationships simultaneously (Ferdinand 2011). The appearance of complex models showed that there is organizational agility, and competitive advantage is a multi-dimensional process with various patterns of tiered causality. Therefore, we need a model as well as an analytical tool that can accommodate the multi-dimensional research. This study used the advantage of SEM, which is its ability to confirm the dimensions of a concept, or the factors used, and its ability to measure the influence that theoretically has been proposed (Ferdinand 2011).

This research employs variables and their item questions from $\mathrm{Lu}$ and Ramamurthy (2011); Volberda (1996, 1997); Gaddis (2000); Roberts and Grover (2012); Ayabakan et al. (2017); (Teece et al. 1997); (Chibelushi and Trigg 2012); (Escandón-Barbosa et al. 2016); (Shafei and Zohdi 2014); and (Qosasi and Permana 2017). However, it combines all the questions and eliminates those that have the same meaning. For the measurement scale, this study posited that Malhotra (2010) stated that the Likert scale submitted to respondents should use a five-point scale. They are 5 (Strongly agree), 4 (Agree), 3 (Nei- ther agree nor disagree), 2 (Disagree), and 1 (Strongly disagree).This study presented all variables measurements as follows (see Appendix A.)

\section{Findings}

This research uses the Structural Equation Model (SEM) analysis technique with Smart Partial Least Square (SmartPLS). SEM with PLS analysis is carried out in three stages, namely the outer model's analysis, inner model's analysis, and hypothesis testing. This study, therefore, discusses the outer model's analysis first.

\section{Outer Model Analysis}

Chin (1998), and Ghozali (2006) recommended that the outer model's analysis should compose of the within construct, or the reliability measured by composite reliability and Cronbach's alpha. All the constructs or variables will be reliable if they have composite reliability values above 0.70 and Cronbach's alpha above 0.60 . While the Average Variance Extracted (AVE) value is sufficient to measure the convergent and discriminant validities if it is more than 0.5 (Chin 1998, Ghozali 2006).The following is the result of the analysis of the outer research model.

\section{Table 1. Cronbach Alpha, Composite Reliability and Average Variance Extracted}

\begin{tabular}{lccccc}
\hline & $\begin{array}{c}\text { Cut-off } \\
\text { Value }\end{array}$ & ICT_Cap & Bus_Agility & $\begin{array}{c}\text { Comp_ } \\
\text { Advantage }\end{array}$ & Explanation \\
\hline $\begin{array}{l}\text { Cronbach's Alpha } \\
\begin{array}{l}\text { Composite } \\
\text { Reliability }\end{array}\end{array}$ & $>0.6$ & 0.92 & 0.92 & 0.92 & All aspects of \\
$\begin{array}{l}\text { Average Variance } \\
\text { Extracted (AVE) }\end{array}$ & $>0.5$ & 0.96 & 0.94 & 0.95 & $\begin{array}{c}\text { small apparel } \\
\text { businesses meet } \\
\text { the standards }\end{array}$ \\
\hline
\end{tabular}

Source: Output SmartPLS 3.0 (2018). 
Table 1 presented the output of the data's analysis, showing that all the variables fulfilled the outer model's criteria. It means that this data analysis concluded that all the variables have proper validity and reliability. Therefore, this study can proceed to the inner model's analysis.

\section{Analysis of the Inner Model}

This research carried out an analysis of the inner, or structural analysis, model to ensure that the structural models were built robustly and accurately. Andrews (1972) introduced the robust regression, which is a regression method used when the data is in an abnormally residual distribution. In other words, the data's distribution has some outliers that affect the model (Andrews 1972). This method is an essential tool to analyze data influenced by some outliers. It means that a model would be resistant to the outliers produced by this regression. An resistant estimates that are not affected by substantial changes in a small part of the data. Meanwhile, it could be small changes in a large part of the data.

This research conducted the inner model's evaluation and discovered several indicators which included the coefficient of determination $\left(R^{2}\right)$; predictive relevance $\left(Q^{2}\right)$; and the Goodness of Fit index $(G o F)$. The following is a presentation for each indicator sequentially.

\section{Coefficient of determination $\left(R^{2}\right)$}

Chin (1998) suggested that a value for $\mathrm{R}$-square of over 0.67 is strong, 0.67 to 0.19 is moderate and below 0.19 is weak. Thus, the statistical results concluded that the model for this research is categorized as having a strong relationship between all of the variables. This research has two endogenous variables namely business agility and
Table 2. Value of R-Square and Adjusted R-Square

\begin{tabular}{lcc}
\hline & $\begin{array}{c}\mathbf{R} \\
\text { Square }\end{array}$ & $\begin{array}{c}\text { Adjusted- } \\
\text { RSquare }\end{array}$ \\
\hline Business Agility & 0.83 & 0.83 \\
$\begin{array}{l}\text { Competitive } \\
\text { Advantage }\end{array}$ & 0.70 & 0.70 \\
\hline
\end{tabular}

Source: Output SmartPLS 3 (2018)

competitive advantage and one exogenous variable. Based on the values of $R$-square and adjusted $R$-square, the statistical result has a strong relationship between the exogenous variable, both independently and simultaneously. Table 2 presented the value of the $R^{2}$ output of the SmartPLS 3 software.

\section{Predictive relevance $\left(Q^{2}\right)$}

This research conducted predictive relevance to determine the model's capability with the blind-folding procedure. According to Chin (1998), if the value obtained is between 0.02 and 0.15 , the model has a small predictive capability. If the value obtained is between 0.15 to 0.35 , the model has moderate predictive capabilities. Finally, if the value obtained is above 0.35 , the model has a high predictive capability.

The following mathematical formula calculates $\mathrm{Q}^{2}$. Moreover, this study used this formula.

$$
\begin{aligned}
& \mathrm{Q}^{2}=1-\left(1-\mathrm{R} 1^{2}\right)\left(1-\mathrm{R} 2^{2}\right) \ldots \ldots\left(1-\mathrm{Rn}^{2}\right) \\
& \mathrm{Q}^{2}=1-(1-0.83)(1-0.70) \\
& \mathrm{Q}^{2}=0.95
\end{aligned}
$$

This study calculated that the $\mathrm{Q}^{2}$ value is 0.95 . It, then, concluded that the model has a high predictive capability. 


\section{The Goodness of Fit Index (GoF)}

Tenenhaus et al. (2005) formulated that the value of GoF is small when it is 0.1 , medium when it is 0.25 , and large when it is 0.38 . This study calculated its GoF values and found that the model has a large $\mathrm{GoF}$ value. It means that the model could represent the real phenomenon. GoF values in SEM with PLS are calculated manually (Tenenhaus (2004) with the formula:

$\mathrm{GoF}=\sqrt{A V E^{2}} \times \mathrm{R}^{2}$

$\mathrm{GoF}=0.80$
This study concluded that the calculation of the GoF value is 0.80 . It, therefore, concluded that the research model could capture the real phenomenon in apparel retailers in Jakarta.

\section{Hypothesis Testing}

This research conducted all the testing of the hypotheses using SEM PLS, carried out with a boot-strapping process that produced $t$-calculated values. If the $t$-calculated value is greater than the t-statistic, with the interval of the confidence level at 95

Figure 1. Full Model of ICT Capability, Business Agility, and Competitive Advantage

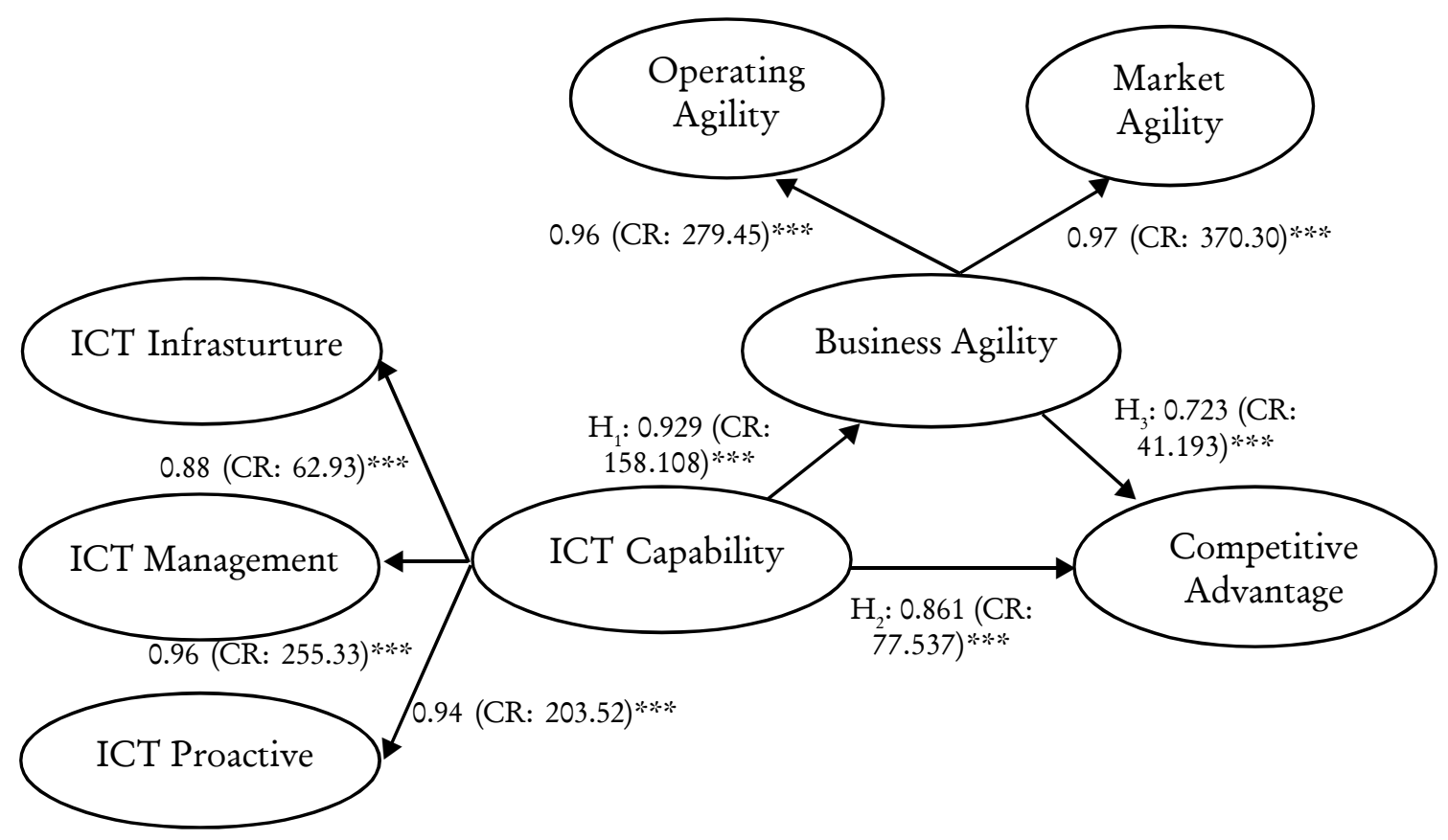

Table 3. Summary of Research Hypothesis Test Results

\begin{tabular}{|c|c|c|}
\hline No & Hypothesis & Results \\
\hline $\mathrm{H}_{1}$ & Firms' ICT capability affects their business agility positively & Supported \\
\hline $\mathrm{H}_{2}$ & Firms' ICT capability affect their competitive advantage positively & Supported \\
\hline $\mathrm{H}_{3}$ & $\begin{array}{l}\text { Firms' business agility influences their competitive advantage } \\
\text { positively }\end{array}$ & Supported \\
\hline
\end{tabular}

Source: Processed by Researchers (2018) 
percent $(>1.96)$, it means that the statistical results supported the hypotheses. The following are the boot-strapping results. This study found the magnitude of the relationship among the variables. Then this study shows the values of the loading factor from its original sample, produced by SmartPLS. The path diagram as Figure 1.

Figure 1 presents the output of the SmartPLS. This statistical result showed that all the hypotheses have t-calculated values that are above 1.96. Table 3 presents a summary of all the results of the hypotheses testing.

\section{The Role of Business Agility as an Mediator}

This study revealed the statistical results of the coefficient of determintation, the predictive relevance and goodness of fit index (Appendix B). Based on the coeeficient of determination, this study found that there is a strong relationship between the exogenous variable, both independently and simultaneously. It means that this model has a large predictive power. Meanwhile, based on the preditive relance test, the calculation of the $\mathrm{Q}^{2}$ value is 0.95 . It also means that this model has a high level of predictive power. Finally, the model has a large GoF value (of 0.80 ), so this model can represent the real phenomenon.

It could be inferred from the three statistical results that business agility mediated the relationship between ICT's capability and competetive advantage. It means that business agility could improve the role of ICT's capability to enhance the competitive advantage of the apparel retailer firms. This study posits the research of Mathiassen and Pries-Heje (2006) and Weill et al. (2002). This article concluded that
ICT investment improved the firms' agility, then continued to enhance the SMEs' competitive advantage. In other words, the SMEs' business agility was triggered by their ICT's capability, and its agility affects each of the SME's competitive advantage due to their improved business agility. It can also be argued that the competitive enhancement has a long-run capacity, due to the initial ICT's capability.

\section{Discussion}

The statistical test results showed that all the research hypotheses are supported. Firms' ICT capabilities have affected their business agility positively and in a statistically significant manner. Firms' ICT capabilities have influenced their competitive advantage positively and significantly. Finally, the firms' business agilities have affected their competitive advantage positively and in a statistically significant manner. All the statistical results are consistent with the research conducted by Yaghoobi et al. (2014) and Qosasi and Permana (2017), showing that their ICT capability has influenced the small businesses' agility positively. Furthermore, their ICT capability affected the small businesses' agility positively because of the existence of sufficient digital capability, which provided many business opportunities, and improved their relationships with customers and resources' suppliers. It means that ICT capability supported the small business actors in their use of digital media or information technology for their business processes and relationship management.

This study highligheted that SMEs' business agility increased when they have the ability to quickly change their tactics or direction. It means that they used their 
ICT to anticipate, adapt, and react to any environmental uncertainties that occurred in their business activities (Grant 2013). Consequently, this study confirmed all the previous research results that showed that small business organizations need to be faster, more flexible and participatory (Sussan and Johnson 2003), and faster, sharper, and more resilient (Wang and Ahmed 2007). This study also confirmed the research of Baker (1996), who stated that, from the perspective of a dynamic capability, the speed and flexibility of their response to market changes is evidence that small businesses could achieve their organizational agility. This study inferred from its subject research that all the apparel retailers had been using ICT, so they are all SMEs that utilize ICT as a tool to enhance their relationship with their customers.

This research confirmed Mathiassen and Pries-Heje (2006) suggestion that companies need to integrate their business processes. It therefore inferred that small businesses should acquire ICT to enhance their agility. Meanwhile, the lack of investment in ICT means that small businesses delay their agility (Weill et al., 2002). The research also concluded that small businesses in the garment trade should not have a short-run focus when they invest in ICT assets. Moreover, managers of small businesses need to understand that investment involves a trade-off between today's earnings and future returns. This study inferred that small businesses should have their focus on a long-run strategy.

The results of this study show that the direct influence of ICT's capability on competitive advantage is smaller than that of the indirect influence. In other words, ICT's influence on a business's agility was not as high as its direct influence on its competi- tive advantage. It means that business agility strengthens the indirect relationship between ICT's capability and competitive advantage. This study agrees with the results of Yaghoobi et al. (2014), which revealed that organizational agility is a source of competitive advantage when it forces competitors to compete and imitate. Organizational agility is the primary source for small businesses to achieve a competitive advantage (Fernandes and Solimun 2017; Wang and Ahmed 2007).

The results of this research confirmed the results conducted by Cakmak and Tas (2012), who examined the effects of digital capability on competitive advantage. The results showed that digital capability has a positive effect on a firm's competitive advantage. The digital capability affected the firm's competitive advantage positively, because having an adequate digital capability could always increase the firm's competitive advantage.

This research supported the previous research conducted by Adietya et al. (2016), which showed that information technology had affected companies' competitive advantage positively. The results of this study also confirmed Qosasi's research (2017) which had examined SEMs in the apparel industry in Jabotabek, using 242 respondents. The results showed that digital capability had affected the small apparel retailers' competitive advantage.

\section{Conclusion}

The phenomena of small businesses acquiring ICT in Indonesia has played an essential role as a driving force for the national economy. These small businesses strive to survive and compete globally with all the competitors in the market. For that 
reason, small businesses must have agility, which creates their competitive advantage. The small business firms could develop their agility through the use of information and communication technology. Organizational agility for the small business firms is a crucial dimension because of two reasons: Firstly, organizational agility has influenced the small businesses' competitive advantage directly, by as much as 69 percent. Secondly, small business firms should enhance their organizational agility so that it strengthens the relationship between their ICT capability and their competitive advantage. In the context of the influence of ICT's capability on competitive advantage, if a company wants to increase its competitive advantage, it should strengthen its organizational agility. This is a fundamental principle.

\section{Practical Implications}

The practical implication of the results of this research is that it could be used as a reference for small business actors to be more active in building their ICT capability. The small businesses should build their ICT capabilities as a necessary part of their infrastructure. ICT infrastructure leads all small businesses to develop efficient processes and governance activities that could reduce their production costs. The small companies could improve their document handling by using financial and accounting software applications, as well as utilizing the management of their communications. The small firms could improve their relationships with stakeholders related to their business activities. They could also undertake their internal management, such as store ownership or company interactions with their staff, suppliers and customers, so that they achieve internal efficiency. The small business firms should have the speed and flexibility to respond to the changes in the market, as a form of achieving their organizational agility. They should manage their organizational agilities' dimensions, which are their operating and market agilities.

\section{Theoretical Implications}

Small business firms generally have operational limitations regarding their businesses' scale, capital and managerial capabilities. Although small business firms could obtain their competitive advantage through their ICT capability and organizational agility, it is not so easy to change a small business into a medium or large business. Even though most small businesses should try to get promoted to the next level, most of them are only able to survive as they are. Therefore, future research can be conducted with an emphasis on the determinants of the transformation process for small businesses to become medium and large ones by involving ICT knowledge as an antecedent variable.

\section{Limitations}

Study's conclusion, practical and theoretical implications need to be into consideration. By the means, this study has several limitations. First, this study collected the data in Jakarta that is a metropolitan city in Indonesia. Business people living in Jakarta are different from the other cities in Indonesia because they have usually faced environmental pressures and high competition. Moreover, firms in Jakarta had been facilitated with higher infrastructures and ICT than other cities in Indone- 
sia. All factors influence the behavioural of business people in Jakarta that is usually more aggressive, competitive, and survival than those in other cities. Second, this study took into research that is apparel retailers. This business has characteristics that are basic needs up to a luxurious one. It means that this business is more durable than busi- ness concentrating on the basic needs only such as food, fruit, fish, and others. Somehow, food and other business would not need great infrastructure and ICT because of their durability. Furthermore, apparel business required marketing strategies proactively, neither did basic needs' business.

\section{References}

Adietya, K., M. Miyasto, and Y. Sugiarto. 2016. Analysis of the Influence of Information Technology and Innovation on Competitive Advantages to Improve Organizational Performance (Studies in food SMEs in the city of Semarang). Diponegoro University, Indonesia.

Andrews, D. F. 1972. Plots of high-dimensional data. Biometrics. https://doi.org/10.2307/2528964

Ayabakan, S., I. R. Bardhan, and Z. Zheng. 2017. A data envelopment analysis approach to estimate it-enabled production capability. MIS Quarterly 41 (1): 189-205.

Bagheri, M. M., A. B. Abdul Hamid, I. Soltani, A. Mardani and E. K. Hazrate-Soltan. 2013. The role of supply chain antecedents on supply chain agility in SMEs: The conceptual framework. Jurnal Teknologi (Sciences and Engineering) 66 (1): 53-60. https://doi.org/10.11113/ jt.v66.1826

Bahrami, H. 1992. The emerging flexible organisation: Perspectives from Silicon Valley. California Management Reviere 34 (4): 33-52.

Baker, D. 1996. Improving vertical jump performance through general, special, and specific strength training: A brief review. Journal of Strength and Conditioning Research. https://doi.org/ 10.1519/00124278-199605000-00015

Barney, J. 1991. Firm resources and sustained competitive advantage. Journal of Management 17 (1): 99-120. https://doi.org/10.1177/014920639101700108

Cakmak, P. I., and E. Tas. 2012. The use of information technology on gaining competitive advantage in Turkish contractor firms. World Applied Sciences Journal 18 (2): 274-285. https:// doi.org/10.5829/idosi.wasj.2012.18.02.744

Chibelushi, C., and D. Trigg. 2012. Internal self-assessment for ICT SMEs: A way forward. International Journal of Business Performance Management 13 (2): 103. https://doi.org/10.1504/ IJBPM.2012.046196

Chin, W. W. 1998. The partial least squares approach to structural equation modelling. Modern Methods for Business Research. https://doi.org/10.1016/j.aap.2008.12.010

Escandón-Barbosa, D., M. Hernandez-Espallardo, and A. Rodriguez. 2016. International market orientation and international outcomes. Global Economy Journal 16 (4), 669-696. https:// doi.org/10.1515/gej-2015-0037

Ferdinand, A. 2011. Research method on the management of research guidelines for writing script. Thesis and Dissertation of Management Sciences ( $3^{\text {rd }}$ ed.). Faculty of Economics and Business, Diponegoro University, Semarang, Indonesia: AGF Books. 
Fernandes, A. A. R., and Solimun. 2017. Moderating effects orientation and innovation strategy on the effect of uncertainty on the performance of the business environment. International Journal of Law and Management 59 (6): 1211-1219. https://doi.org/10.1108/IJLMA-10-20160088

Gaddis, P. O. 2000. Adaptive enterprise -Creating and leading sense-and-respond organizations. Long Range Planning 33 (2): 268-271. https://doi.org/10.1016/S0024-6301(00)00018-2

Ghozali, I. 2006. Multivariate Analysis Application with SPSS Program. Semarang, Indonesia: Diponegoro University Publishing Agency.

Goldman, S. L., R. N. Nagel, and K. Preiss. 1995. Agile Competitors and Virtual Organisations Measuring Agility and Infrastructure for Agility. London: Van Nostrand Reinhold, International Thomas Publishing.

Grant, A. 2013. Givers take all: The hidden dimension of corporate culture. McKinsey Quarterly 2: 52-65. Retrieved from http://libezproxy.open.ac.uk/login?url=http:// search.ebscohost.com/login. aspx?direct $=$ true $\& \mathrm{db}=$ bth $\& A N=87315651 \&$ site $=$ edslive\&scope $=$ site

Grant, R. 1996. Toward a knowledge-based theory of the firm. Strategic Management Incomplete nameàplease ccheck int link

Journal 17 (S2): 109-122. https://doi.org/10.1002/smj.4250171110

Hair, J. F., A. H. Money, P. Samouel, and M. Page. 2006. Research Methods for Business. Education and Training 49 (4). https://doi.org/http://dx.doi.org/10.1108/et.2007.49.4.336.2

Jared, D., G. Orwa, and M. Oloko. 2015. The Relationship between Dynamic ICT Capabilities and Competitive Advantage of Technical, Vocational and Entrepreneurship Training Institutions in Western Kenya Region. International Journal of Academic Research in Business and Social Sciences 5 (8) (August).

Judge, W. Q., and A. Miller. 1991. Antecedents and outcomes of decision speed in different environmental context. Academy of Management Journal 34 (2): 449-463.

Liu, C. H. S., and Y. P. Fang. 2016. Night markets: Entrepreneurship and achieving competitive advantage. International Journal of Contemporary Hospitality Management. https://doi.org/ 10.1108/IJCHM-03-2015-0114

Lu, Y., and K. R. Ramamurthy. 2011. Understanding the link between information technology capability and organizational agility: An empirical examination. MIS Quarterly. https:// doi.org/10.1007/978-3-642-49298-3

Malhotra, N. K. 2010. Marketing Research: An Applied Orientation (6 ${ }^{\text {th }}$ ed.). Pearson.

Mathiassen, L., and Pries-Heje, J. 2006. Business agility and diffusion of information technology. European Journal of Information Systems. https://doi.org/10.1057/palgrave.ejis.3000610

Newbert, S. L. 2008. Value, rareness, competitive advantage, and performance: A conceptual-level empirical investigation of the resource-based view of the firm. Strategic Management Journal 29 (7): 745-768. https://doi.org/10.1002/smj.686

Nguyen, T. N. Q. 2010. Knowledge management capability and competitive advantage: an empirical study of Vietnamese enterprises.

Penrose, E. 1959. Theory of the growth of the firm. Theory of the Growth of the Firm. Published to Oxford Scholarship Online (November 2003). 
Porter, M. E. 1985. Competitive advantage. Strategic Management. https://doi.org/10.1108/ eb054287.

Power, D. J., A. S. Sohal, and S-U. Rahman. 2001. Critical success factors in the agile supply chain management-An empirical study. International Journal of Physical Distribution and Logistics Management 31 (4): 247-265.

Roberts, N., and V. Grover. 2012. Leveraging information technology infrastructure to facilitate a firm's customer agility and competitive activity: An empirical investigation. Journal of Management Information Systems 28 (4): 231-270. https://doi.org/10.2753/MIS07421222280409.

Sambamurthy, V., A. Bharadwaj, and V. Grover. 2003. Shaping agility through digital options: Reconceptualizing the role of information technology in contemporary firms. MIS Quarterly 27 (2): 237. https://doi.org/10.2307/30036530.

Shafei, R., and M. Zohdi. 2014. Relational capabilities in market orientation to the improvement of performance outcomes in SMEs. International Journal of Business Performance Management 15 (4): 295. https://doi.org/10.1504/IJBPM.2014.065009.

Singh, P., J. A. Parker, and A. Nadim. 2007. Employee relations in small businesses: examining under-developed issues. International Journal of Human Resources Development and Management 7 (3/4): 335. https://doi.org/10.1504/IJHRDM.2007.017138.

Somsuk, N., J. Wonglimpiyarat, and T. Laosirihongthong. 2012. Technology business incubators and industrial development: a resource based view. Industrial Management and Data Systems, 112(2), 245-267. https://doi.org/10.1108/02635571211204281.

Sussan, A. P., and W. C. Johnson. 2003. Strategic capabilities of the business process: looking for a competitive advantage. Competitiveness Review: An International Business Journal 13 (2), $46-52$.

Teece, D. J. 2007. Explicating dynamic capabilities: The nature and microfoundations of (sustainable) enterprise performance. Strategic Management Journal 28 (13): 1319-1350. https:// doi.org/10.1002/smj.640.

Teece, D. J., G. Pisano, and A. Shuen. 1997. Dynamic capabilities and strategic management. Strategic Management Journal 18 (7): 509-533. https://doi.org/10.1002/(SICI)10970266(199708)18:7 < 509::AID-SMJ882 > 3.0.CO;2-Z.

Teece, D., and S. Leih. 2016. Uncertainty, innovation, and dynamic capabilities: An introduction. California Management Review 58 (4): 5-12. https://doi.org/10.1525/cmr.2016.58.4.5.

Tenenhaus, M., V. E. Vinzi, Y-M. Chatelin, and C. Lauro. 2005. PLS path modelling. Computational Statistics and Data Analysis 48 (1), 159-205.

Tsourveloudis, N., K. Valavanis, D. Gracanin, and M. Matijasevic. 1999. On the measurement of agility in manufacturing systems. In Proceedings of the $2^{\text {nd }}$ European Symposium on Intelligent Techniques.

Uden, L. 2007. Activity theory for designing mobile learning. International Journal of Mobile Learning and Organisation. https://doi.org/10.1504/IJMLO.2007.011190

Volberda, H. W. 1996. Toward the flexible form: How to remain vital in hypercompetitive environments. Organization Science. https://doi.org/10.1287/orsc.7.4.359

Volberda, H. W. 1997. Building flexible organisations for fast-moving markets. Long Range Planning. https://doi.org/10.1016/S0024-6301(96)00110-0 
Wang, C. L., and P. K. Ahmed. 2007. Dynamic capabilities: A review and research agenda. International Journal of Management Reviews. https://doi.org/Doi 10.1111/J.14682370.2007.00201.X.

Weill, P., M. Subramani, and M. Broadbent. 2002. IT infrastructure for strategic agility.

Wernerfelt, B. (1984). A Resource-based view of the firm. Strategic Management Journal, 5 (2), 171-180. https://doi.org/10.1002/smj.4250050207

Werr, A., J. Blomberg, and J. Löwstedt. 2009. Gaining external knowledge - boundaries in managers' knowledge relations. Journal of Knowledge Management. https://doi.org/10.1108/ 13673270910997114

Wiklund, J., and D. Shepherd. 2003. Knowledge based resources, entrepreneurial orientation, and the performance of small and medium sized businesses. Strategic Management Journal 24 (13): 1307-1314.

Yaghoobi, N. M., M. Bakhshimazdeh, and M. Alikhasi. 2014. Analysing key concepts of organisation: knowledge management, competitive intelligence and competitive advantage. International Journal of Services and Operations Management 18 (3): 321. https://doi.org/ 10.1504/IJSOM.2014.062234.

Yaghoubi, N.-M., and N. Tajmohammadi. 2011. E-commerce application in the insurance industry; a review of organisational factors. European Journal of Scientific Research 60 (2): 268272. Retrieved from https://www.scopus.com/inward/record.uri?eid=2-s2.080053210256\&partnerID = 40\&md5 = 24a5873309092d5fb1f17d6ae9a7ae1d

Yusuf, Y. Y., M. Sarhadi, and A. Gunasekaran. 1999. Agile manufacturing:: The drivers, concepts and attributes. International Journal of Production Economics 62 (1-2): 33-43. 
Qosasi et al.

\section{Appendix A. Operational Variables}

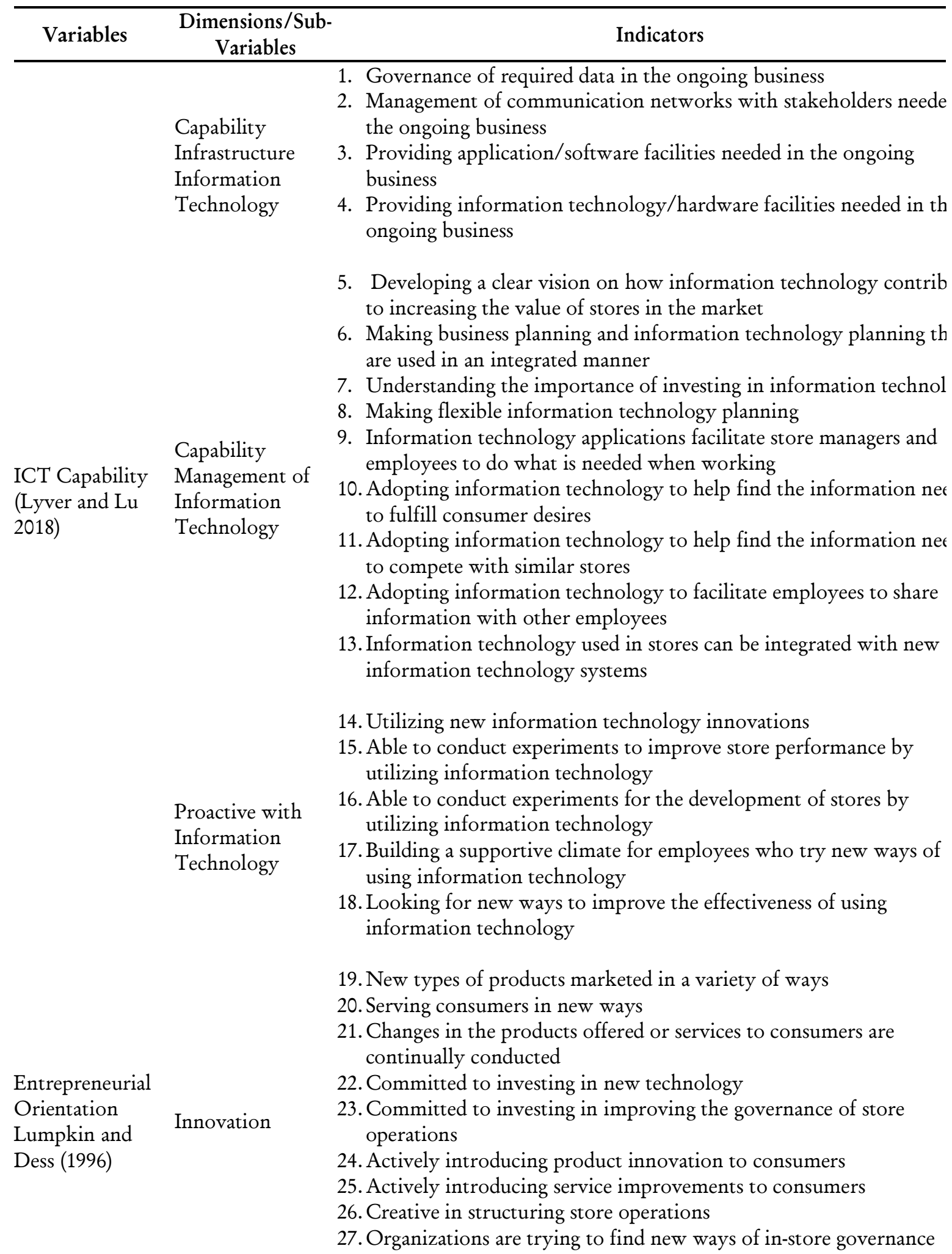




\section{Appendix A. Continued}

\begin{tabular}{ccc}
\hline Variables & $\begin{array}{c}\text { Dimensions/Sub- } \\
\text { Variables }\end{array}$ & Indicators \\
\hline
\end{tabular}

1. Supporting the efforts of individuals and/or teams that work independently

2. Individual employees and/or teams are given the opportunity to decide for themselves what business opportunities they want to pu

3. Individuals and/or teams who pursue business opportunities are gi

Autonomy the opportunity to make their own decisions without constantly referring to their supervisors

4. Employees' initiatives play a major role in identifying/choosing entrepreneurial opportunities

5. Employees' inputs play a major role in identifying/choosing entrepreneurial opportunities

6. Trying to pioneer new products and then responding to being followed by competitors

7. Starting by introducing new service styles to consumers then responding to being followed by competitors

Proactive

8. Initiating in improving organizational governance then responding being followed by competitors

9. Initiating in utilizing information technology in the store then responding to being followed by competitors

10. Monitor the development of technological trends and then identify future consumer needs

11. Trying to make itself unable to be followed by competitors

12. Trying aggressively in the market

13. Trying to be competitive in the market

Aggressiveness in 14. Adopting a price-cutting strategy to increase competing positions competition 15. Duplicate the business practices of successful competitors to impro competing positions

16. Use unique/unusual ways to challenge competitors

17. Having the principle that the higher business has the higher probability of return

18. Taking the bold steps needed to achieve the company's goals

19. Allocating large amounts of capital so that stores can grow

Risk-taking 20. Developing stores through large capital loans

21. Store managers are supported to take risks when running new idea

22. Trying to encourage employees to look for new opportunities

23. Trying to encourage employees to experiment/experiment on new opportunities 
Qosasi et al.

\section{Appendix A. Continued}

\begin{tabular}{|c|c|c|}
\hline Variables & $\begin{array}{c}\text { Dimensions/Sub } \\
\text { Variables }\end{array}$ & Indicators \\
\hline \multirow{2}{*}{$\begin{array}{l}\text { Organizational } \\
\text { Agility } \\
\text { (Lu and } \\
\text { Ramamurthy } \\
\text { 2011) }\end{array}$} & $\begin{array}{l}\text { Agility in } \\
\text { adjusting to the } \\
\text { store's operation }\end{array}$ & $\begin{array}{l}\text { 1. Trust the ability of the store's employees to respond to customers' } \\
\text { requests quickly } \\
\text { 2. Trust the ability of the store's employees to respond to special/uni } \\
\text { requests from customers } \\
\text { 3. Can quickly increase or decrease the level of service in order to adj } \\
\text { to fluctuations in the consumers' demand in the market. } \\
\text { 4. Quickly make alternative adjustments to the store's internal } \\
\text { operations as needed. }\end{array}$ \\
\hline & $\begin{array}{l}\text { Agility in } \\
\text { utilizing the } \\
\text { market }\end{array}$ & $\begin{array}{l}\text { 5. Quickly make decisions to face market changes } \\
\text { 6. Make the right decisions to face market changes } \\
\text { 7. Quickly implement the right decisions to face market changes } \\
\text { 8. Keep trying to find better ways to serve the market } \\
\text { 9. Trying to re-engineer the organization to find better ways to serve } \\
\text { market. }\end{array}$ \\
\hline $\begin{array}{l}\text { Competitive } \\
\text { Advantage } \\
\text { (Liu and Fang } \\
\text { 2016) }\end{array}$ & & $\begin{array}{l}\text { 10. Able to combine the resources and the ability to reduce operating } \\
\text { costs to a more effective level than those of other similar stores } \\
\text { 11. Able to combine resources and abilities to take advantage of } \\
\text { opportunities, to be able to exploit opportunities more completely } \\
\text { than other similar stores } \\
\text { 12. Able to combine resources and abilities to take advantage of } \\
\text { opportunities to be able to explore (seek) new opportunities throu: } \\
\text { trial and error more efficiently than other similar stores } \\
\text { 13. Able to combine resources and abilities to defend themselves from } \\
\text { various competitive threats that exist in the market } \\
\text { 14. Trying to find ways to maintain excellence in competition } \\
\text { 15. Recognized as being superior at identifying opportunities in the } \\
\text { market than other similar stores. }\end{array}$ \\
\hline
\end{tabular}

Source: Processed by the Researchers (2018) 


\section{Appendix B}

Rbo_A

\begin{tabular}{lccccc}
\hline & $\begin{array}{c}\text { Original } \\
\text { Sample }\end{array}$ & $\begin{array}{c}\text { Sample } \\
\text { Means }\end{array}$ & $\begin{array}{c}\text { Standard } \\
\text { Deviation }\end{array}$ & t- Statistic & P-Value \\
\hline Business Agility & 0.927 & 0.928 & 0.006 & 145.806 & 0.000 \\
Competitive Advantage & 0.926 & 0.926 & 0.006 & 145.556 & 0.000 \\
ICT Capability & 0.939 & 0.939 & 0.005 & 190.725 & 0.000 \\
\hline
\end{tabular}

\section{Cronbach Alpha}

\begin{tabular}{lccccc}
\hline & $\begin{array}{c}\text { Original } \\
\text { Sample }\end{array}$ & $\begin{array}{c}\text { Sample } \\
\text { Means }\end{array}$ & $\begin{array}{c}\text { Standard } \\
\text { Deviation }\end{array}$ & t- Statistic & P-Value \\
\hline Business Agility & 0.923 & 0.923 & 0.007 & 136.062 & 0.000 \\
Competitive Advantage & 0.923 & 0.923 & 0.007 & 136.905 & 0.000 \\
ICT Capability & 0.919 & 0.919 & 0.008 & 122.308 & 0.000 \\
\hline
\end{tabular}

\section{Composite Reliability}

\begin{tabular}{lccccc}
\hline & $\begin{array}{c}\text { Original } \\
\text { Sample }\end{array}$ & $\begin{array}{c}\text { Sample } \\
\text { Means }\end{array}$ & $\begin{array}{c}\text { Standard } \\
\text { Deviation }\end{array}$ & t- Statistic & P-Value \\
\hline Business Agility & 0.963 & 0.963 & 0.003 & 304.887 & 0.000 \\
Competitive Advantage & 0.940 & 0.940 & 0.005 & 187.558 & 0.000 \\
ICT Capability & 0.949 & 0.948 & 0.005 & 209.070 & 0.000 \\
\hline
\end{tabular}


Qosasiet al.

\section{Appendix B (Continued)}

Average Variance Extracted

\begin{tabular}{lccccc}
\hline & $\begin{array}{c}\text { Original } \\
\text { Sample }\end{array}$ & $\begin{array}{c}\text { Sample } \\
\text { Means }\end{array}$ & $\begin{array}{c}\text { Standard } \\
\text { Deviation }\end{array}$ & t- Statistic & P-Value \\
\hline Business Agility & 0.929 & 0.929 & 0.006 & 158.108 & 0.000 \\
Competitive Advantage & 0.723 & 0.723 & 0.018 & 41.193 & 0.000 \\
ICT Capability & 0.861 & 0.860 & 0.011 & 77.537 & 0.000 \\
\hline
\end{tabular}

R-Square Adjusted

\begin{tabular}{lccccc}
\hline & $\begin{array}{c}\text { Original } \\
\text { Sample }\end{array}$ & $\begin{array}{c}\text { Sample } \\
\text { Means }\end{array}$ & $\begin{array}{c}\text { Standard } \\
\text { Deviation }\end{array}$ & t- Statistic & P-Value \\
\hline Business Agility & 0.831 & 0.831 & 0.014 & 59.040 & 0.000 \\
Competitive Advantage & 0.700 & 0.701 & 0.023 & 30.412 & 0.000 \\
\hline
\end{tabular}

\section{$R$-Square}

Original Sample Standard t-Statistic P-Value Sample Means Deviation

\begin{tabular}{llllll}
\hline Business Agility & 0.831 & 0.832 & 0.014 & 59.194 & 0.000 \\
Competitive Advantage & 0.702 & 0.701 & 0.023 & 30.601 & 0.000 \\
\hline
\end{tabular}

